\title{
MYANMAR BRONZES AND THE DIAN CULTURES OF YUNNAN
}

\author{
Elizabeth Howard Moore
}

School of Oriental and African Studies (SOAS), Department of Art \& Archaeology, London; em4@soas.ac.uk

\begin{abstract}
Bronze artefacts from the Samon Valley (circa $19-22^{\circ} \mathrm{N}, 95-$ $97^{\circ} \mathrm{E}$ ) in central Myanmar are strikingly similar to pieces from Lijiashan, $80 \mathrm{~km}$ south of Kunming, Yunnan. The affinities to Lijiashan are greater than those to the larger and more renowned cemetery of Shizhaishan. The dates of the Samon Culture overlap with the earlier Dian cemeteries. Most of the Samon finds are not found outside Myanmar, such as small wire packets, floral ornaments and 'mothergoddess' figures. The Samon Valley and Upper Myanmar may be the areas referred to in Chinese texts as beyond the 'barbarian' regions that came under Han control in the early centuries CE. And, as seen in Yunnan at this time, the Samon Culture may have experienced political change reflecting Han expansion and fluctuating alliances between Myanmar, Yunnan, and South Asia.
\end{abstract}

\section{INTRODUCTION - MYANMAR AND YUNNAN BRONZES}

Bronze artefacts excavated since 1998 from the Samon Valley of central Myanmar have identified a new Bronze-Iron Age culture. The greatest concentration of sites is along the short Samon River but the sites are located over a distance of $230 \mathrm{~km}$ along a north - south axis from Halin (Wetlet Township, $\left.22^{\circ} 29^{\prime} 7.57^{\prime \prime} \mathrm{N}, 95^{\circ} 51^{\prime} 3.58^{\prime \prime} \mathrm{E}\right)$ to Lewe $\left(19^{\circ} 38^{\prime} 2.49^{\prime \prime} \mathrm{N}\right.$, $96^{\circ} 66^{\prime} 39.88^{\prime \prime} \mathrm{E}$ ) (Figure 1). In the same region there are sites of the as yet undated Neolithic, first millennium CE Buddhist, 14th to 17th century CE Inwa (Ava) and 19th century CE Mandalay periods. The few absolute dates for the Samon Culture are c. $600 \mathrm{BCE}-400 \mathrm{CE}$, with hints of occupation dating to 900 BCE (Pautreau et al. 2006, 2007:87). In 2009, excavations at Ywa Gon Gyi, Thazi, a possible Neolithic habitation layer was unearthed below Iron Age mortuary layers (Coupey 2009:3). However, the overall relationship of cemeteries to habitation sites in the Samon and Chindwin river valleys remains unclear as most excavations are cemetery sites. Most of the Samon bronzes are not seen outside
Myanmar, including 'mother-goddess' figures, bronze packets (kye doke), floral ornaments, swords and axes. There are also semi-precious stone rings, glass rings and beads with some generic forms, such as spherical carnelian beads. Other artefacts, including green stone beads in the shape of an elephant and carnelian beads in the shape of a tiger with a cub in the mouth, are unique to Myanmar. Most, but not all, of the bronzes and other Samon artefacts appear to have been manufactured from local resources. In addition to metals and -precious stones, the Samon region has salt deposits and cotton production. Many of these goods were also valued in Yunnan, with cotton and salt traded with Nanchao in the later first millennium CE (Guy 1995:67).

Some bronzes from the Samon region appear to have been imported from Shizhaishan and Lijiashan, near Kunming. These include Heger I cowrie-drum containers, musical instruments, and ritual ladles or mouth organs. There are also parallels in burial traditions between the Samon Valley and the Yunnan sites around Kunming. For example, recent Shizhaishan excavations yielded headless burials and disarticulated inhumations that recall the 'mother-goddess' figures and disarticulated burials from Samon sites (Jiang Zhilong 2003; Pautreau 2007). The presence of both local and imported mortuary goods and the hints of similar burial customs in the Samon and Kunming regions highlight the significance of overland exchange between Central Myanmar and Yunnan. The primary, but not exclusive, trade route appears to have been along the Dhotawaddy (Myit Nge) River extending northeast from Mandalay to the present Chinese border at Muse. The northeast links to Muse were balanced by networks to the northwest and the Chindwin River.

The principal excavated site in the Chindwin Valley is Nyaunggan, Budalin, Sagaing Division (22²4'43.04"N, 95 3'34.14"E) located $85 \mathrm{~km}$ west of Halin and $300 \mathrm{~km}$ northwest of Lewe. This area of Upper Myanmar was easily traversed overland or via the Ayeyarwaddy (Irrawaddy) and Chindwin rivers. Among the finds excavated from Nyaunggan in 1998-2001 were bronzes comparatively dated 




Figure 1. Regional map.

to c. 1500 BCE. However, most of the sites around Nyaunggan are non-metal sites, so the bronzes mark an elite burial area. The graves yielded a number of objects that ap- pear to have been imitated or appropriated by the somewhat later Samon Valley cultures. This pattern of cultural appro- 
priation recalls that of sedentary Kunming peoples by equestrian Dian seen in Yunnan artefacts (Calo' 2008).

Artefacts found in the Lower Chindwin and Samon regions are compared below, following a summary of relevant aspects from the Dian sites. The article concludes by highlighting the role of trans-regional exchange in the transition from Neolithic villages to Bronze-Iron Age chiefdoms and the subsequent emergence of Buddhist kingdoms.

\section{Dian and Upper Myanmar cultures}

The Dian Culture is best known for its bronze artefacts, particularly the graphic figures on lids of cowrie-drum containers excavated in the $1950 \mathrm{~s}$ and $1990 \mathrm{~s}$ at Shizhaishan $\left(25^{\circ}\right.$ $\left.37^{\prime} 31.89^{\prime \prime} \mathrm{N}, 100^{\circ} 17^{\prime} 7.08^{\prime \prime} \mathrm{E}\right)$ and Lijiashan $\left(24^{\circ} 24^{\prime} 34.84^{\prime \prime} \mathrm{N}\right.$, $\left.102^{\circ} 45^{\prime} 1.64 " \mathrm{E}\right)$. Lijiashan was excavated again in 1991-1992 and Shizhaishan in 1996. Shizhaishan artefacts from these recent excavations date to the Spring and Autumn Period (722-481 BCE) and middle of the Warring States Period (403-221 BCE). The dates, existence of ancestral veneration, and certain traits of these goods are similar to inhumations in the Samon Valley. However, Samon bronzes and their correlation to social change are different from the situation of Yunnan. The introduction of bronze was a threshold of social augmentation in China but not in mainland Southeast Asia, where such social change comes with the use of iron (Wang 2008). Higham and Higham (2009) have used a large body of absolute dates from Thailand to support this argument. While a comparable dataset is not yet available for Myanmar, their conclusion applies well to the Myanmar evidence described below.

\section{Lower Chindwin Bronzes}

In 1998, the Fine Arts Department, Ministry of Culture, undertook excavation of a cemetery on the northwest rim of an extinct volcano adjacent to the village of Nyaunggan, Budalin Township, Sagaing Division, $\left.22^{\circ} 24^{\prime} \mathrm{N}, 95^{\circ} 04^{\prime} \mathrm{E}\right)$. Excavations revealed a range of inhumation burials, stone rings, pottery, and bronze implements, dated to 1500-1000 BCE (Figure 2). Due to the absence of collagen remaining in bone samples, no absolute dates are available and the chronology remains comparative. The burials were supine inhumations, although a large pot with a skull and a number of large jars were found. There was a degree of social differentiation at the Nyaunggan cemetery. However, compared to the burials of the Samon Culture, there were fewer mortuary goods, only bronze weapons, no 'mother-goddess' figures, no kye doke (wire packets), no floral ornaments, and no glass or iron artefacts.

There are copper deposits in the Nyaunggan area that were used to manufacture bronze spears, axes, and ge, halberd-like implements akin to those in Yunnan (Chiang 2010). Local volcanic stones were used to make at least five differ- ent shapes of stone beads and rings (square, egg-shaped, triangular, round or pinion). These were placed on various parts of the body including the shoulder, arm, and pelvis. The most abundant grave good was pottery, ranging from small oil lamps and cups to large urns and 'distillation' vessels. Eightyeight shell beads were recovered; these were perhaps used as amulets (San Nyein 1999:79). The shells are from the family Nassariidae, a marine species; the larger shells are Peeled-



Figure 2. Chindwin artefacts

spire Dog Whelks (Nassarius leptospirus) and the smaller shells are Humped Dog Whelks (Nassarius camelus) (Ken Ross, Australian Department of Health \& Ageing, and Richard C. Willan, Senior Curator, Molluscs, Museum \& Art Gallery of the Northern Territory, Darwin, Australia, pers. comm., December 2008). While the existence of marine shells may suggest exchange with southern coastal areas, the finds may also indicate that the seacoast once stretched far into the central region of modern Myanmar (Tin Tun, Yangon University; Kyaw Kyaw Htay, Dawei University, pers. comm., December 2008). If this hypothesis is verified, the shells could indicate a different ecology for this arid (675 $\mathrm{mm}$ per annum) region two thousand years ago.

\section{Samon Culture - changing geographical context}

The artefactual evidence indicates that the Samon Culture was a central node networked in all directions (Figure 3 ). The region today is comprised of populations from many different ethnic groups. The clearest influences to the Samon Culture are from Yunnan and possibly Sichuan, but Chindwin riverine connections to the northwest may have also affected the Samon culture. In addition to the Dhotawaddy (Myit Nge) River, there are the Chaung Magyi, Shweli and Taping (Tabein) rivers and overland trade routes. There were 


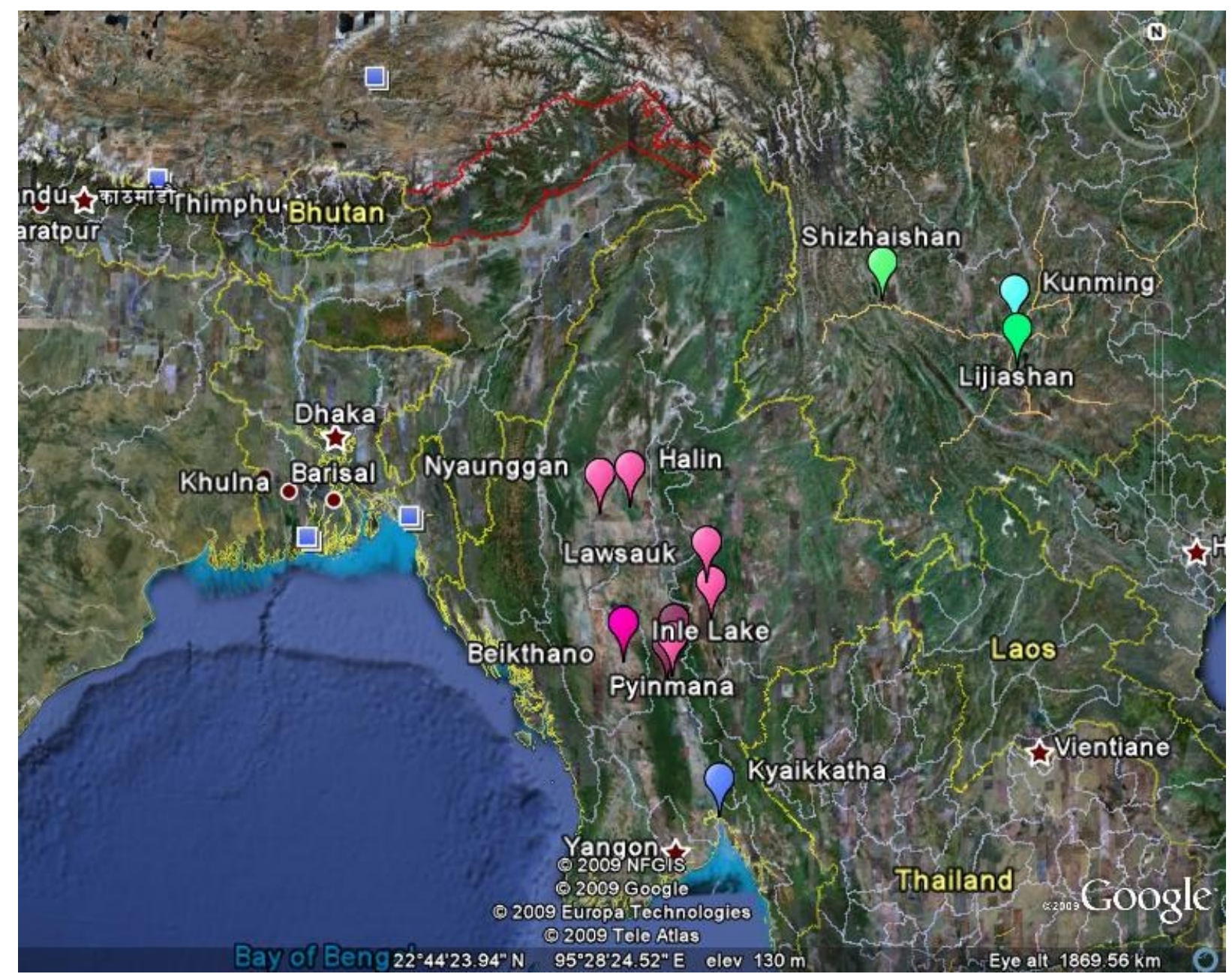

Figure 3. Chindwin Samon Lijiashan map

also trade routes from the Samon to the south by river and overland.

Samon artefacts have been found around Inle Lake $\left(20^{\circ}\right.$ $\left.36^{\prime} 17.89^{\prime \prime} \mathrm{N}, 96^{\circ} 54^{\prime} 42.54^{\prime \prime} \mathrm{E}\right)$ and near Lawsauk $\left(21^{\circ}\right.$ $15^{\prime} 2.13^{\prime \prime} \mathrm{N}$, 96 $\left.51^{\circ} 48.40^{\prime \prime} \mathrm{E}\right)$. Inhumation burials in limehardened earthen graves with carnelian beads with white line designs found near Lewe (Pyinmana) mark the southern reach of the Samon culture documented to date (T.Tan; Win Maung (Tampawady), pers.comm., June 2008). Lewe lies in a $25 \mathrm{~km}$ long region of intermittent streams south of the Samon that is thought by Myanmar geologists to have been connected south to the Sittaung River and the Andaman Sea. A maritime connection for the Samon culture would introduce additional trade contexts in which to assess the ritual norms of the Samon culture (Moore 2009; 2010). Finds such as the Dog Whelks in Chindwin burials (noted above) and hydrological evolution in the Samon River highlight long term changes to the Upper Myanmar environment.

\section{Comparison of the Chindwin and Samon cultures}

Mortuary wealth differed in the Chindwin and Samon regions. Chindwin goods were principally stone rings, bronze weapons, and pottery. The copper resources of the Chindwin Valley are more concentrated than those of the Samon and, while evidence of copper smelting has been found in the Chindwin region, stone moulds for bronze axes have been found in the Samon. The hard volcanic stones around Nyaunggan and other craters in the Chindwin region appear to have been traded to the Samon Valley but most of the rings from the Samon Valley are from local stones or glass. In addition, 'T-shaped' or flanged round rings are found in the Samon Valley, while the rings in the Chindwin Valley have an inner hole with flat edges polished to create a smooth surface. In the Samon Valley, there are also bronze ritual goods, glass discs, some iron implements, and line-decorated or zoomorphic semi-precious stone beads. None of these have been found in the Chindwin area. 
The walled site of Halin (c. 100-800 CE) stands out in the Samon Valley distribution for several reasons, highlighting its prominence as a trading centre. Emissaries from the 9th century Chinese court recognized a P'iao or Pyu capital, perhaps Halin, at the time when Tibeto-Burman rule was established at Nanchao (Backus 1978:83-89; Guy 1995:64$5)$. Some Halin wall fortifications, and its later role as a guard post, may date to this period of political consolidation and religious transformation in Yunnan. Halin is outside the Samon Valley proper, but a large quantity of Samon and also Chindwin artefacts have been found there. Excavation since 2004 of site HL25-28, southeast of the city, has provided much in situ data, with evidence of inhumation (Hudson 2009; Nyein Lwin, pers.comm., January 2010).

Despite Halin's proximity to Yunnan, this important site has not yet yielded bronzes imported from Yunnan. The imported goods come instead from around Pyawbwe $\left(20^{\circ} 35^{\prime} 0^{\prime \prime}\right.$ N $96^{\circ} 4^{\prime} 0^{\prime \prime}$ ), in the southern part of the Samon Valley. This suggests that Halin was an interchange point between the Chindwin and the Samon cultures but leaves its relationship to Lijiashan unclear. The Samon Culture's appropriation of Chindwin mortuary custom is seen in the miniaturization of grave goods and, possibly, the use of Chindwin halberdshaped axe motifs in 'mother-goddess' figure frames. The balance of Chindwin-Samon artefacts thus provides a useful context for assessing the varying relationship of Halin and the southern Samon area around Pyawbwe to Lijiashan and other Yunnan sites. Significant Samon artefacts are described in two parts below: locally produced and imported goods.

\section{Local Samon bronzes}

The most striking locally made Samon bronze artefacts are the 'mother-goddess' figures, first recorded in 1998. (There are possible parallels in headless figures from Chengdu but I have only seen photographs of these.) The figures appear to have been produced by beaten relief in a similar manner to Myanmar bronze gongs, as were the majority of locally produced bronzes. The 'mother-goddess' figures are slim with round breasts and a womb beaten into smooth hemispheres; the leg bones and backbone are also in relief. The figures measure $60-90 \mathrm{~cm}$ long and have one to three torsos joined at breast and hip. They are headless (unless the curved neck is seen as a head) or they had a wooden or metal mask where the head would be. The figures are narrow, probably due to their use affixed to the top of coffins, carved from tree trunks or made from bamboo mats (Coupey 2009:2; Pautreau et al. 2003:61). Another local object is a flat floral ornament that was fixed to the sides of coffins (Win Maung (Tampawady) 2002-03:126-143).

The most ubiquitous bronze artefacts are kye doke, packets of pulled wires, $1.5-7.5 \mathrm{~cm}$ long (Figure 4). Although tests have yet to be carried out on the imported bronzes, the packets are more than 98\% copper (Moore 2008; Pau- treau et al. 2007). The $0.5 \mathrm{~cm}$ thick wires of the kye doke were 'tied' into bundles with wire and wrapped, with traces of cotton remaining on the surface. Skeletons had up to thirty bundles, their shape akin to bundles of growing or harvested rice stalks in the Halin region today. The packets also recall bundled ears of rice and barnyard millet from Haimenkou in the Erhai Lake area of Yunnan, where they are seen as an indicator of settled agriculture and animal husbandry (Kan Yong 1985: 26). It has also been suggested that the kye doke denoted age, were needles, or were ingots; the Yunnan parallels point to markers of wealth (Pautreau et al. 2001:100; Ian Glover, pers. comm., September 2004).

Other Samon bronzes are similar to pieces from Shizhaishan and Lijiashan but simpler. The axes $(7-9 \mathrm{~cm})$ are elongated with horizontal or vertical lines on the shaft, recalling pieces from Yunnan sites such as Daxingzhen and Jinguan but different from Chindwin axes, which are more rounded (Moore 2007:96; Kan Yong 1985:72, Fig. 14). The narrow Samon bronze spears are not elaborately decorated but have affinities to Shizhaishan examples (Murowchick 2002:161, Fig. 8). Spears in the Samon region were also made in miniature $(\mathrm{c} .4 \mathrm{~cm})$ and bundled into packets found in the hands or underneath the wrist of skeletons. These objects have been recovered from excavations and also villager digging.

Many irrigation works have been constructed in the Samon region over the last decade. In addition, the Samon beads are valued by collectors. As a result, villager 'beadhunting,' prior to Department of Archaeology excavations, has brought many grave goods to the antiquities market. These items are often not found in excavations. For example, over a dozen 'mother-goddess' figures are in private collections but none have yet been formally excavated. Given the rapid economic development of the region, these unprovenanced goods need to be included in profiling the Samon culture.

A prime example of the unprovenanced Samon artefact is a small $(13 \mathrm{~cm})$ bronze 'bird-man' pole found by a villager near Badi Gon, Pyawbwe (Moore 2007: 16,110) (Figure 5). The pole was inside a finely made bronze box containing a second standing human figure. The posture of the 'bird-man' closely resembles a bronze figure $(\mathrm{c} .15 \mathrm{~cm})$ from Liajiashan described as a Dian man kneeling on a drum. The Liajiashan figure decorates the end of a bronze spoon $(39.5 \mathrm{~cm})$, used as a ritual ladle in the Warring States period (475-221 BCE), from burial no.11 of Lijiashan cemetery (Hong Kong Museum of History 2004:87, Pl. 045). This type of vessel is also found in the Samon, one piece having two figures on the end carrying a long drum or possibly bamboo tubes with tea. The Samon 'bird-man' and the Lijiashan spoon depict the man in a squatting position with calves drawn closely up against the thighs. 

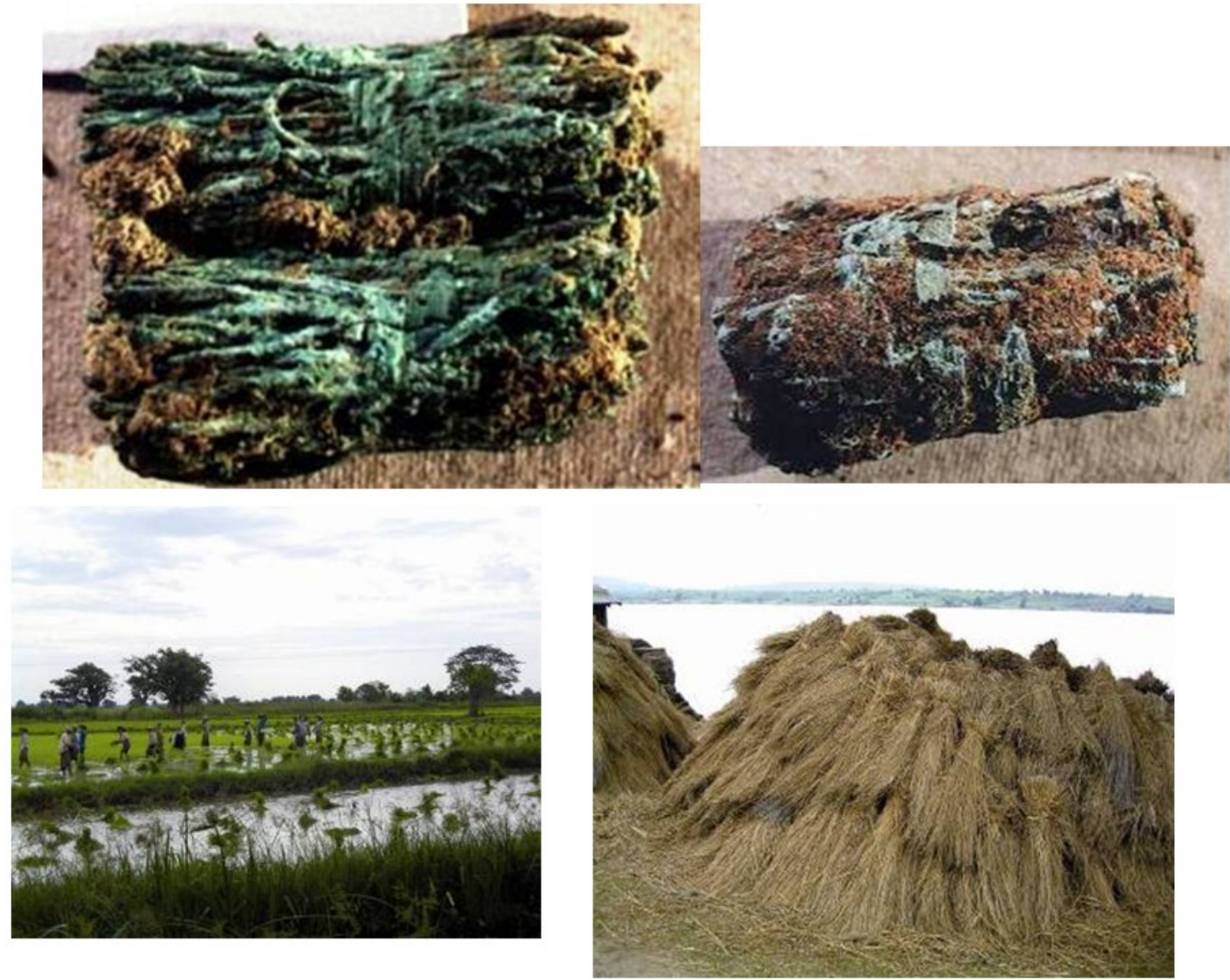

Figure 4. Kye doke (bronze packets) and rice chaff bundles

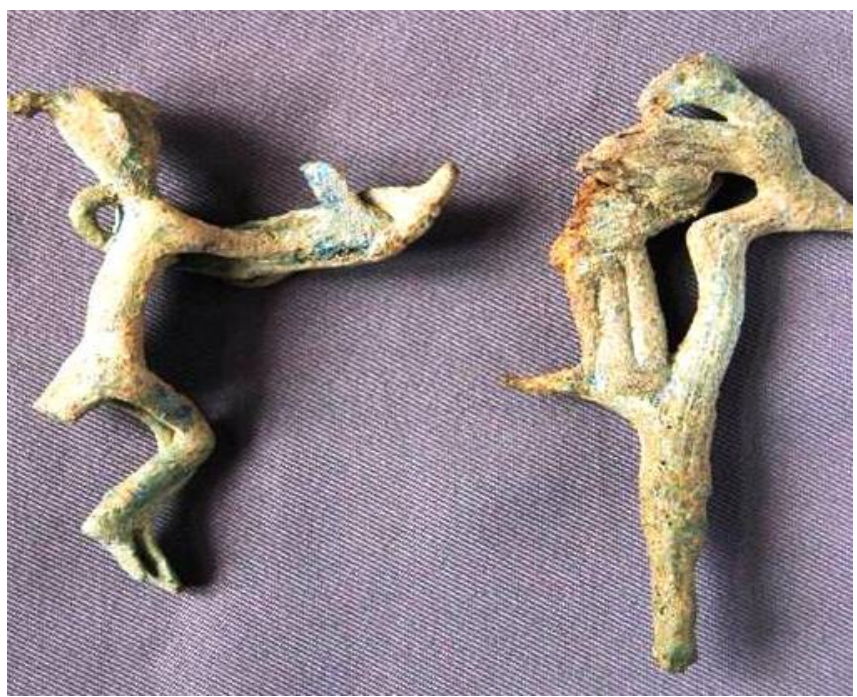

Figure 5. Bird-man pole, courtesy T. Tan 
In the Samon 'bird-man,' the figure is 'held' by a bird with flexed legs and the section of the pole below the figure is unclear, whereas the Lijiashan piece has a 'drum'. The arms of both the Lijiashan and Samon figures are crossed on upturned knees. The head of the Samon piece is broken off, but the second figure in the Samon box, depicting a man proffering a long boat-like object, has a head with a similar to the Lijiashan figure with an off-center topknot. The legs of the Samon 'boat' figure are carefully made, the right knee being marginally drawn up and the flat foot slightly extended to the rear as if in motion. The dress is uncertain, but the ankles may have a trouser-like lower rim. A thick bronze ring is affixed to the upper back as if to suspend the piece.

The 'bird-man' and 'boat' figures were set in the bronze box facing each other. The box has slightly flared sides giving it a length of $14-18 \mathrm{~cm}$. It has a tall lid $(12 \mathrm{~cm})$ made by fixing rectangular sheets together, recalling the manufacture of the much larger and more elaborate Dabona house-shaped coffin (Cremin 2010: Fig. 6). The surface is detailed in the manner of a cane-woven basket, with diagonal crossed woven bands on the body. Three narrower horizontal bands on the bottom and two on the top, below an inset flange, were made to nest the lid. The box with lid measures $21 \mathrm{~cm}$. The box's meaning is uncertain, but the workmanship and iconography point to an elite, possibly ancestral, ritual use.

\section{Trade bronzes}

Local bronzes included 'mother-goddess' figures, floral ornaments, kye doke packets, axes and spears. Several appear to have been made by beating rather than casting. Very different pieces are probably prestige trade items from Yunnan, principally Lijiashan: mouth organs, ladles, and bronze drums. One ladle found in the Samon region has a long handle $(35 \mathrm{~cm})$ with a gourd-shaped bowl (10 cm diameter) on one end and two human figures on the others end (Candido et al. 1987:52, Fig. 10 [60 cm, $1.4 \mathrm{~kg}$ ]; 64, fig. 21 [39.5 cm, 394gm]). The human figures are carrying a long object, possibly a drum or bamboo tubes (as noted above for the 'bird-man' box). A second piece is a $20 \mathrm{~cm}$ high slender, gourd-shaped vessel akin to hula sheng mouth-organs. The mouth of the gourdshaped vessel found in the Samon region is open (or damaged). Dian pieces were pierced for insertion of pipes and in some cases are surmounted by a bull (Murowchick 2002:167, Fig. 13 [28.2 cm]; Candido et al. 1987:64, Fig. 22 [35.5 cm, $2.72 \mathrm{~kg}]$ ) (Figure 6).

Bells have also been found in the Samon. One is thickly cast, $15 \mathrm{~cm}$ tall with a $2 \mathrm{~cm}$ lug and flat braided bands at the top and bottom, akin to the border on amour from Lijiashan (Murowchick 2002:162, Fig. 10; Candido et al. 1987:50-1, Fig. 8 [9.5 x $13 \mathrm{~cm}, 342 \mathrm{gm}])$. A second bell is smaller and rounder (10 cm height and diameter), unadorned apart from a series of faces incised near the bottom. These are 'right side up' when the bell is held upside down, and are lively childlike sketches of a face (Moore 2007:107-111).

Five or six Heger I drum-cowrie containers have been found in Myanmar, all with mushroom-shaped mantles decorated with feather-headdress men, bulls, and rice barns on stilts (Calo' 2007:75). One drum, found a number of years ago in the relic chamber of the Shwezigon pagoda, is also of this type and closely resembles a piece found in Chieng Mai (Calo' 2007:75). Two are a rare Heger I Type with a star and geometric motifs but without the elaborate headdress figures. There is also a Wanjiaba type drum found at Sin Bo between Myitkyina and Bhamo, Kachin State. Additional fragments have been recorded by Win Maung (Tampawaddy) from drums northeast of Mandalay. Another was found at a Bronze -Iron Age burial site by Yetagon Taung in the Shan foothills east of Mandalay. Two drum fragments have bird designs, an egret in one case and a plump bird perched on the hindquarters of a spotted bull with a hump and possibly dewlaps in the other (Cremin 2010). Another Heger I drum (H. 40.5 cm, D. $51 \mathrm{~cm})$, classified as a Dong Son Type A and today kept in Sagaing, has a boat on the upper mantle and 'feather-men' and a rice barn on the tympanum (Moore 2007:103-104, 242) (Figure 7). As noted below, cowries such as those stored in these drums were among the beads excavated in the Samon Valley. No drum-cowrie containers with threedimensional figures on the tympanum giving a highly graphic picture of Dian culture have been found.

\section{Iron, beads, and pottery}

Relatively few iron artefacts have been found in the Samon area and no iron was found in the Chindwin excavations. It is possible, as suggested for the Dian region, that the iron pieces represent the later phases of the culture (Allard 1999:78). The most common Samon iron artefact is a broad petalshaped blade $(8-12 \mathrm{~cm})$ set in a finely made bronze hilt (Win Maung (Tampawady) 2002-03). The hilts $(7-10 \mathrm{~cm}$ in length) have a slender oval-shaped cross-section decorated with spirals and concentric circles around the midsection and rows of parallel incised lines on either end (Moore 2007:107; Win Maung (Tampawaddy) 2002-03:256). In their workmanship and decoration, they are akin to daggers from a number of Dian sites and may have been produced in Yunnan (Kan Yong 2002:160).

The numerous finely polished Samon beads are made from carnelian, green chalcedony, and fossil wood (Campbell -Cole 2003; Glover and Bellina 2001). The beads were often found on skeletons, together with one to ten small polished green, grey-green or maroon-brown pebbles possibly used for finishing pottery (Nigel Chang, pers.comm., December 2008). The pebbles were always in physical contact with the neck, arms or legs of the skeleton, as seen in burial S56 with seven grey and one white pebbles, four bronze packets, and four translucent red stone beads and two very small flat 



Figure 6. "Mother-Goddess" figures, courtesy Win Maung (Tampawaddy)

pebbles, approximately $12 \mathrm{~cm}$ to one side (Pautreau et al. 2007).

Perhaps the most spectacular bead form is the carnelian tiger, which in various materials and forms has been recorded in Central Thailand and southern China (Bellina in Pautreau et al. 2007:73). However, in the Samon region there are many finds of tiger beads, most bearing a small cub, in white, chocolate, red and many hues of orange stone (Moore 2007:100$101,117)$. The tigers have been likened to symbols of authority such as the bronze inscribed 'Tally Tigers' of the Qin dynasty (207-221 BCE) (Hudson 2002:1, Fig. 8; Murowchick 2002:162, Fig. 10; Pautreau et al. 2007:111). Shells were also used as beads, with cowries found in Samon excavations highlighting the trade in cowries from the Andaman Sea to Yunnan. In addition, glass beads and rings were abundant in Samon burials. Some of the ring shapes recall stone rings from the Lower Chindwin region while others are multiple round bangles found on the arms of skeletons. One long spiked bronze armlet has also been recorded at Halin that may have been imported from Yunnan.

In the Chindwin region Nyaunggan excavations, pottery was the most abundant mortuary good, but this figure drops considerably in the Samon region where graves contained other indicators of wealth and status, specifically bronze and beads (Hudson 2004:89-90). Of particular note is the distinctive form of what have been provisionally called 'distillation' pots. Based on ethnographic parallels from the Halin area, the vessels may have been used to produce an alcoholic liquid. They are pedestal pots with three perforated cylinders on the upper surface of the pot's shallow bowl. When used, this would have supported a collection vessel placed below an upper pot with cool water that prompted vapor from the perforations to distil. Functional 'distillation' vessels are seen in the Lower Chindwin, although to date only the nonfunctional variety (some $4 \mathrm{~cm}$ diameter) has been recovered from Samon sites (Moore 2007:93-94; Win Maung 2002$03)$. It is possible that the fermented substance produced with 


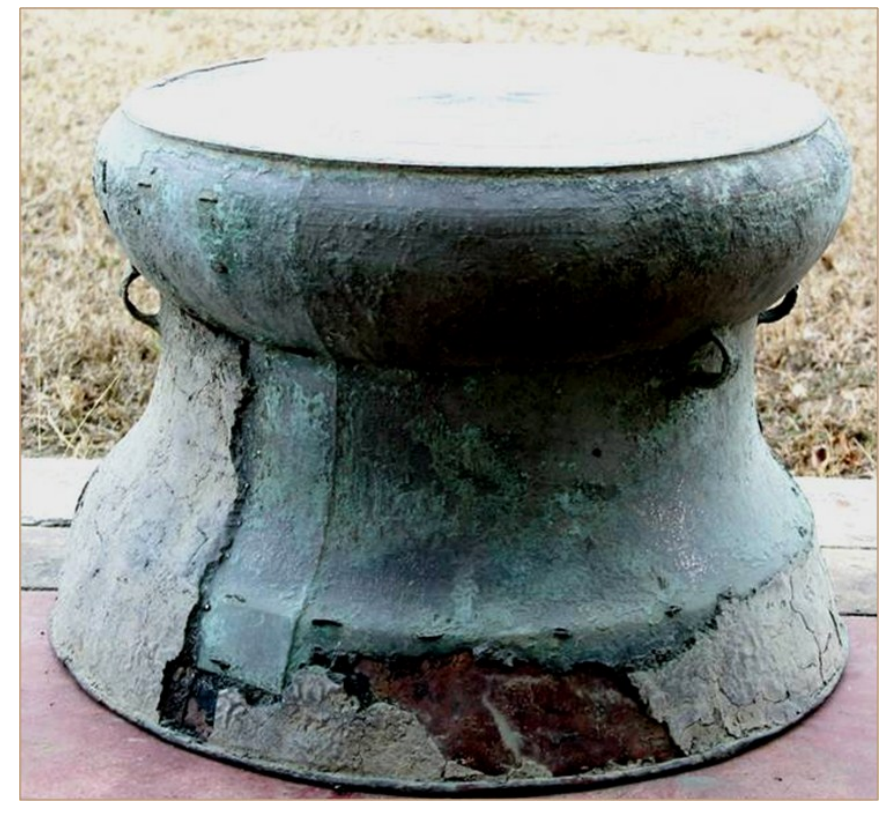

Figure 7. Sagaing drum, courtesy Win Muang (Tampawaddy)

the pots was used for ritual purposes, explaining its later production in miniature. Relevant motifs occur on bronze drums from Guang-nan, East Yunnan showing tall jars being dipped with libation cups (Dewall 1981:335, Fig. 48.1, 337-8, Fig. 48.6).

While conjectural, the ritual distillation fits with the blossoming display of wealth seen in the Samon burials, a more complex ranking of social status compared to the Lower Chindwin region. The Chindwin goods seen in miniature in the Samon imply an appropriation of resources and trade routes that as noted earlier recalls the appropriation of sedentary peoples by equestrian Dian seen in Yunnan artefacts. Increasing Samon wealth is also highlighted by a number of large elephant tusks found by Myauk Mee Kon villagers. These are analogous to tusk deposits from near Chengdu, central Sichuan where some 70 tusks were found with lifesize bronze human heads, 'spirit trees', jades, and ritual vessels dated to the late second millennium BCE (Murowchick 2002:140).

\section{CONCLUSIONS}

The Samon Culture is not directly mentioned in Myanmar traditional histories or chronicles, but these may allude to earlier troubled times with the repeated conquering of fabulous animals, such as flying white tigers and giant boars. Chronicles are often relegated to 'myth' but carry important social memory, highlighting the need to redefine 'tradition' in contexts quite different from Europe. This is particularly the case in the Buddhist culture in Myanmar where the past can be seen as active in the present. A parallel exists in Tibet where understanding of time, history, and chronology have highly developed local meanings which have evolved over long periods (Galey 2007:215-216, 235-236; Hobsbawm and Ranger 1983/1992; Repo 2010). The Samon Culture findings are the first bridge between the Buddhist chronicles and prehistoric beliefs. Data from the Samon Culture is increasing with more excavation and documentation. This is providing new interpretations very different from the prior focus on descriptive empirical data. The Samon Culture is in these ways a major change to both the history and the discipline of archaeology in Myanmar.

As in the Dian region, Samon studies remain artefact typologies and burial descriptions rather than being able to define different categories of sites (Allard 1999:85). It is clear that Upper Myanmar was not a simply a 'Dian' cultural sphere but a distinct development needing local definitions. Again, seen in the Dian region, this appears to have been 'a process of locally driven amalgamation and transformation of diverse non-local elements' in a multi-ethnic 'heterogeneous cultural environment' (Allard 1999:84). Given the many significant implications of the Samon and Yunnan relationship, the question of 'first' or origins becomes simplistic.

Comparison of Samon artefacts to Yunnan shows particular links to Lijiashan, a smaller and less renowned site than Shizhaishan. Thus, the Samon finds bring Myanmar into a discourse of wider overland and maritime exchange c. 500 $\mathrm{BCE}$ to $800 \mathrm{CE}$. Regional trade included bronze vessels from Yunnan and cowries, cotton, salt and possibly tea from the Samon (Moore 2009a; Tan 2009). Further investigation may also be merited in Tibet in relation to the 'musk route' (Philip Denwood, pers. comm., 2008). East of the salt-rich Namtso Lake and the Damxung region, the $\mathrm{Nu}$ River within eastern Tibet then turns south as the Thanlwin (Salween) of the Shan Plateau. Of note are stone implements with 'distinct rounded shoulders and arched blades' of the $\mathrm{Nu}$ and Lancang. These are seen later around Lake Er linked to ecological changes and movements of peoples in the second millennium BCE (Chiou-Peng 2008: 34-43, 40-1). While the climate and materials differ from Myanmar, the seasonal movement of livestock in Tibet recalls Myanmar traditions of ancient migration from the 'northwest'. Seasonal migration may also have prompted use of in-gyi, or seasonal lakes, that were vital in the transition from the Bronze-Iron Age chiefdoms and to Buddhist kingdoms.

The Chindwin and Samon artefacts bespeak multiple origins, with the 'Ah-thi' or original people of Samon Valley perhaps providing a refuge for sedentary dwellers around the Dian and Xingyun lakes of the Shizhaishan and Lijiashan Cultures (Than Tun 2005: iii). The two regions have similar profiles of wet rice agriculture and animal husbandry. The sedentary to equestrian Dian profile of cultural appropriation has parallels in Myanmar with the seeming taking of motifs 
and materials from the Chindwin to the Samon. This suggests a local origin connected to the northwest and not a north to south movement of technology. Again, however, searching for a singular origin can be misleading for there were multiple routes of interchange. The Samon Culture, rich though it may have been, died out with increasing Han domination and the growing 'Sinicization' of artefacts from Yunnan (ChiouPeng 2008: 34-43).

The Samon and Upper Myanmar Cultures may have been recognized by the Han but only as lying beyond the 'barbarian' regions of Yunnan. The transition from BronzeIron Age to Buddhist polities in Myanmar was catalyzed by trade with South Asia, Yunnan, and Central Asia. This included a rapid increase in iron production, more sophisticated exploitation of seasonal lakes, use of semi-precious stones and gems, and precious metals, such as silver and gold. It was not necessarily a smooth transition with an abrupt shift from Yunnan to South Asia in the politics and culture of Myanmar perhaps correlated to Han expansion and fluctuating relations between Yunnan, Tibet, and the Han court. When understood in this context, Myanmar moves from being a 'buffer' between South Asia and China to center stage in the changing kingdoms of first millennium CE South and East Asia.

\section{ACKNOWLEDGEMENTS}

I thank the British Academy for its support enabling me to attend the Hanoi conference.

\section{REFERENCES}

Allard, F. 1989. The archaeology of Dian: trends and traditions. Antiquity 73:77-85.

Backus, C.R. 1978. The Nanchao Kingdom and frontier policy in South-West China during the Sui and T'ang periods. Cambridge: Cambridge University Press.

Calo', A. 2007. Transitions of a feathered world: The distribution of bronze drums in early Southeast Asia. Unpublished Ph.D. thesis, Department of Art \& Archaeology, SOAS, London.

2008. Heger I bronze drums and the relationship between Dian and Dong Song cultures. In E. Bacus, I. Glover, and P. Sharrock (eds.), Interpreting Southeast Asia's past, pp. 208-224. Singapore: National University of Singapore Press.

2009. Transitions of a feathered world: The distribution of bronze drums in early Southeast Asia. Oxford: British Archaeological Reports.
Campbell-Cole, B. 2003. Ancient hard stone beads and seals of Myanmar. In I. Glover, H. Hughes Brock and J. Henderson (eds.), Ornaments from the Past: Bead Studies after Beck, pp. 118-133. London: Bead Study Trust.

Candido, A., R. Ciarla and P. Negro. 1987. I bronzi del regno di Dian, Yunnan, Cina (secoli VI/I AC). Rome: Associazione Italia/Cina.

Chiang, P. 2010. The ge of the Shiazhaishan culture complex. Paper presented at the 19th Congress of the Indo-Pacific Prehistory Association, Hanoi.

Chiou-Peng, T. 2008. Dian bronze art: Its source and transformation. Bulletin of the Indo-Pacific Prehistory Association 28:34-43.

Coupey, S. 2009. Excavations at Ywa Gon Gyi, Upper Burma. Bioarchaeology in Southeast Asia and the Pacific: Newsletter 5 (April):1-3.

Cremin, Aedeen. 2010. Seeing Dian through barbarian eyes. Paper presented at the 19th Congress of the Indo-Pacific Prehistory Association, Hanoi.

Galey, H. 2007. Ontology of the past and its materialization in Tibetan treasures. In O. Hammer and J.R. Lewis (eds), The inventory of sacred tradition, pp. 213-239. New York: Cambridge University Press.

Glover, I.C. and B. Bellina. 2001. Alkaline etched beads east of India in the late prehistoric and early historic periods. Bulletin de l'École Française d'Extrême-Orient 88:191215.

Guy, J. 1995. The Avalokitesvara of Yunnan and some South East Asian connections. In R. Scott and J. Guy (eds.), South East Asia and China: Art, interaction and commerce, pp. 64-84. London: Percival David Foundation, University of London.

Higham, C. and T. Higham. 2009. A new chronological framework for prehistoric Southeast Asia, based on a Bayesian model from Ban Non Wat. Antiquity 83:12544.

Hobsbawm, E. and T. Ranger (eds). 1983/1992. The invention of tradition. Cambridge: Cambridge University Press.

Hong Kong Museum of History. 2004. Hunting and rituals: Treasures from the ancient Dian Kingdom of Yunnan. Hong Kong: Hong Kong Museum of History. 
Hudson, B. 2002. Bronze mother-goddesses, carnelian tigers and radiocarbon dates: Some recent discoveries and new research directions in the archaeology of Burma up to the 11th to 13th century AD Bagan period. Paper presented at the 17th Congress of the Indo-Pacific Prehistory Association, Taipei.

2004. The origins of Bagan. Internet published Ph.D. dissertation, Department of Archaeology, University of Sydney.

2009. Recent excavations, conservation and presentation of inhumation burials at Halin, Myanmar (Burma). Bioarchaeology in Southeast Asia and the Pacific: Newsletter 5 (April):3-7.

Moore, E. 2007. Early landscapes. Bangkok: River Books.

2008. Myanmar archaeology: Tagaung and 'Pyu'. In J-P Pautreau, S. Coupey, E. Rambault, and V. Zeitoun (eds.), From homo erectus to the living traditions: choice of papers from the 11th International Conference of the European Association of Southeast Asian Archaeologists: Bougon, 25th-29th September 2006, pp.183-192. Chiang Mai: Siam Ratana.

2009. Archaeology of the Shan Plateau, the Bronze to Buddhist transition. Contemporary Buddhism X/ X: 83-102.

2009a. The beginnings of Buddhist archaeology and the Shan Plateau. Shan Studies Conference, Chulalongkorn University 15-18 October, 2009.

2010. Cultural exchange between Myanmar and Yunnan circa 600 BCE-400 CE. In L.Ghosh and T. Sen (eds). Southern Silk Route: Historical links to contemporary convergences.

Murowchick, R. 2002. The political and ritual significance of bronze production and use in ancient Yunnan. JEAA 12:133-92.

Pautreau, J.P., U Pauk Pauk and K. Domett. 2001. Le cimetière de Hnaw Kan, Malhaing (Mandalay), Note Préliminaire. Aséanie 8:73-102. 65 .

2003. Le cimetière de Hnaw Khan. Culturelles: 58-

Pautreau, J.P., A. Coupey, P. Mornais, Aung Aung Kyaw. 2006. Bronze and Iron Age burials in the Samon River Valley. In L. Bacus, I. Glover, and V. Piggott (eds). Uncovering Southeast Asia's past - Selected papers from the Tenth Biennial Conference of the European Associa- tion of Southeast Asian Archaeologists, the British Museum, London, pp. 128-36. Singapore: National University Press.

Pautreau, J.P. (ed.). 2007. Ywa Htin: Iron Age burials in the Samon Valley, Upper Burma. Chiang Mai: Siam Ratana and Mission Archéologique Française au Myanmar.

Repo, J. 2010. Tibetan refugee architecture. Unpublished Ph.D. in progress, Department of Art \& Archaeology, SOAS, London.

San Nyein. 1999. Beads from Nyaunggan. In UHRC (eds). Proceedings of the Workshop on Bronze Age culture in Myanmar, pp. 78-80. Yangon: Universities' Historical Research Centre (UHRC).

Tan, T. 2009. Tea and beads: Archaeology, ethnography and trade on the Shan Plateau. Paper presented at the Shan Studies Conference, Bangkok.

Tun, T. 2005. Jambudipa. Yangon: Myanmar Historical Commission.

von Dewall, M. 1981. New evidence on the ancient bronze kettle-drum of South East Asia from recent Chinese finds. In B. Allchin (ed.), South Asian Archaeology, pp. 334-40. Cambridge: Cambridge University Press.

Wang, T. 2008. Pottery to bronze: A cultural and technological transition in early China. Paper presented at SOAS 1, 29 January.

Win, M. (Tampawady). 2002-3. Sa-Mon River Valley Civilization: Recent information from field exploration. IndoAsiatische Zeitschrift 6/7:126-143.

Yong, K. 1985. The bronze culture of Yunnan. Bulletin of the Ancient Orient Museum, Tokyo 7:47-92.

Zhilong, J. 2003. New excavations at Shizhaishan, Yunnan, and implications for the archaeology of the ancient Dian Kingdom. Bulletin of the Indo-Pacific Prehistory Association 18 (Melaka Papers, Vol. 2):117-120. 